DOI: https://doi.org/10.32839/2304-5809/2021-4-92-9

удК 373.3.31

Дубовик С.Г., Перепелиця Л.Ф.

Київський університет імені Бориса Грінченка

\title{
ФОРМУВАННЯ В УЧНІВ ПОЧАТКОВОЇ ШКОЛИ ВМІННЯ БУДУВАТИ РІЗНІ ТИПИ ТЕКСТІВ
}

\begin{abstract}
Анотація. У статті розглянуто методичні засади формування в учнів початкової школи вміння будувати різні типи текстів на уроках української мови. Подано загальні рекомендації щодо організації роботи над зв’язним висловлюванням у початковій школі. Конкретизовано типи текстів, які розглядаються в початковому курсі української мови. Схарактеризовано особливості побудови текстів різних типів. Зазначено пріоритетні напрями роботи вчителя на уроках формування текстотворчних умінь молодших школярів. Визначено основні завдання уроків із формування в учнів уміння будувати різні типи текстів. Описано основні підходи до організащії роботи з формування в молодших школярів уміння створювати тексти різних типів на уроках української мови в початковій школі. Визначено види мовленнєвих вправ і завдань, які доцільно застосовувати під час навчання учнів складати різні типи текстів.
\end{abstract}

Ключові слова: текст, типи текстів, розповідь, опис, міркування, текстотворчі вміння, формування вміння будувати різні типи текстів.

Dubovyk Svitlana, Perepelytsia Liliia Borys Grinchenko Kyiv University

\section{FORMATION OF THE SKILLS TO BUILD THE TEXTS OF DIFFERENT TYPES BY THE PRIMARY SCHOOL PUPILS}

Summary. The methodological bases of formation of the skills to build the texts of different types by the primary school pupils in the lessons of Ukrainian language have been studied. The construction of the texts of different types has been characterized. The types of texts that are included to the programme of Ukrainian language in the primary school have been specified. The recommendations on the organization of work to improve the coherent speech of primary school pupils have been given. Three stages of the organizational and methodological system of work have been introduced. In particular, at the first stage, the teacher must explain to the children the principles of the topic related to the type of text, and clarify the nature of each type of text, using specific examples. The second stage has been revealed as the stage of practical learning and the acquisition of skills related to the pupils' ability to recognize the types of texts. The third stage has been presented as the final process of mastering the material, in which the pupils learn how to create various types of texts without help. The types of exercises and tasks that are advisable to use on the lessons to teach the children to compose various types of texts have been determined. The first type of exercises is related to the reading small fragments of texts and the characteristics of this text. The second type of exercise is a multiple choice exercise. It has been stressed that information technologies should be involved in the creation of tests, in particular, Google services, which are freely available. The third type of exercises is creative exercises related to the tasks of writing a text of a certain type (story, description, reasoning, essay). The prospects for further research on the problem of forming the ability of primary school students to build different types of texts have been outlined. In particular, it has been noted the importance of the question of development of new expedient methods and techniques of work that will activate the process of forming text-making skills. The elaboration of the system of exercises and tasks, which is aimed at developing in elementary school pupils the skills to build various types of texts, has been indicated as a challenge. The use of modern information and telecommunication technologies for the formation of text-making skills of pupils has been underlined as an inevitable necessity.

Keywords: text, types of texts, story, description, reasoning, text-making skills, the formation of the ability to build various types of texts.

$\Pi$ остановка проблеми. Навчання української мови в початковій школі є складним процесом, що вимагає врахування багатьох фракторів, які пов'язані з розвитком мовлення дитини, формуванням її як мовної особистості, яка не тільки знає мову, а й уміє нею користуватися як засобом спілкування, пізнання і вирішення найважливіших життевих задач. Вивчення рідної мови є важливим не лише з погляду мовної освіти, а й для світоглядного становлення особистості молодшого школяра, виховання громадянина своєї держави.

На нашу думку, для ефективного навчання української мови необхідне розроблення організаційних і методичних заходів щодо фрормування в учнів насамперед текстотворчих умінь, передбачених типовою освітньою програмою української мови для початкової школи. Один із актуальних напрямів, що потребуе розроблення нових організаційно-методичних засад, пов'язаний із мовленневим розвитком учнів, фрормуванням уміння будувати різні типи текстів.

В українській мові існуе три типи текстів: розповідь, опис і міркування. У текстах-розповідях передають дію в розвитку, у часовій послідовності; у текстах-описах характеризують статичні картини, передають їх деталі; у текстах-міркуваннях подають розвиток думок щодо предмета промови. Усі типи текстів широко використовуються під час мовлення і спілкування. На нашу думку, дуже важливим завданням учителя початкової школи на уроках української мови $є$ насамперед навчання молодших школярів самостійно складати тексти різних типів. 
Аналіз останніх досліджень і публікацій. Проблема формування в учнів початкової школи текстотворчих умінь висвітлена в наукових працях багатьох учених-педагогів, зокрема Миколи Вашуленка, Олени Лобчук, Надії Луцан, Катерини Пономарьової, Наталії Богданець-Білоскаленко, Тетяни Кохно, а також інших дослідників [1-7].

Аналіз результатів досліджень науковців дозволив зробити висновок про те, що проблема розвитку текстотворчих умінь молодших школярів є актуальною і потребуе глибинного розгляду. Зокрема, детального вивчення і подальшого розроблення потребують питання, що стосуються формування в учнів початкової школи вміння будувати різні типи текстів.

Мета статті. Головною метою статті є розроблення методичної системи роботи щодо оволодіння учнями початкових класів умінням створювати тексти різних типів.

Виклад основного матеріалу дослідження. Уміння створювати власні висловлювання набувають надзвичайно важливого значення в умовах сучасного інформаційного суспільства. Уміння самостійно складати різні типи текстів є базовим у системі текстотворчих умінь учнів початкових класів.

Текстотворчі вміння - це насамперед уміння будувати тексти, працювати 3 текстом, розрізняти тему тексту, добирати заголовок, визначати основну думку, ключові слова, формулювати висновок на основі прочитаного (почутого) тексту. Важливими $є$ також й інші вміння, необхідні для роботи з текстом, - «уміння оріентуватися в побудові тексту і ділити текст на смислові частини, уміння аналізувати кожну частину тексту і передавати зміст кожної з них, уміння виділяти головне і визначати фактичну й емоційну інфрормацію» [8, с. 35].

Зазначимо, що текстотворчі вміння дослідники розподіляють на групи [7]: уміння наповнювати текст змістом, що вимагає від учня знання матеріалу, про який він плануе писати текст; уміння правильно будувати текст, що забезпечуе якість його сприйняття читачем; індивідуальні мовленневі вміння і навички, що пов'язані 3 різними аспектами мовлення: правильність висловлювань, ясність висловленої думки, багатство і краса мовлення; уміння учня працювати над текстом із метою його вдосконалення, розширення або скорочення.

У наукових працях вітчизняних дослідників детально розкрито сутність і зміст зазначених текстотворчих умінь, зазначаеться, що ці вміння $є$ надзвичайно важливими для мовленневого розвитку учнів початкової школи, формування в них комунікативної компетентності [7].

Розглянемо методичні аспекти проблеми формування в учнів початкової школи вміння будувати різні типи текстів. Цей процес передбачає наступні етапи: осмислення змісту тексту, оцінку його змістових складників, виділення основної думки та ключових слів. Така робота над створенням текстів спрямована на формування в учнів умінь, які пов'язані з загально-фрілософськими методами дослідження: «учні набувають такі вміння: аналізувати, синтезувати, порівнювати інформацію; оцінювати навчальні дії відповідно до поставлених завдань; працювати з алгоритмом редагування тексту» [9, с. 128].
Робота з формування вміння створювати різні типи текстів $е$ надзвичайно важливим складником методики навчання української мови і мовлення. Проте, у сучасній початковій школі на уроках цьому питанню приділяеться недостатньо уваги, що призводить до того, що учні не завжди звертають увагу на те, над яким типом тексту вони працюють і не замислюються над змістом створюваного тексту. Таким чином, одне з основних завдань учителя початкової школи на уроках української мови - сформувати в молодших школярів уміння будувати різні типи текстів (розповіді, описи, міркування).

На нашу думку, на першому етапі робота вчителя мае бути спрямована на навчання молодших школярів розпізнавати типи текстів. Це творчий процес, який вимагає уважної, зосередженої роботи учнів над змістом текстів різних типів. Учень має прочитати текст, усвідомити його зміст, дати відповіді на окремі запитання, що стосуються його сутності. Глибоке осмислення тексту розвиває у дітей уміння і навички, пов'язані 3 аналізом тексту, критичним мисленням, тощо. Робота над текстом i, зокрема, над визначенням його типу, до якого він належить, сприяе насамперед формуванню в учнів уміння зосереджуватися, бути уважними, а також мовленневому розвитку молодших школярів у цілому.

Ми вважаємо, що процес формування в молодших школярів уміння розпізнавати типи текстів мае здійснюватися шляхом усвідомлення учнями змісту та проведення аналізу всього тексту та його смислових частин. 3 цією метою вчитель мае пояснити дітям, що кожен із типів текстів означає, дібрати приклади таких текстів. Детально розглянемо кожен із трьох типів текстів та їхні основні характеристики.

Текст-розповідь повідомляе про певні події, які відбулися, або відбуваються. У цьому типі тексту використовуються дієслова минулого або теперішнього часу; розповідь може йти від першої, або другої особи. За змістом такий тип тексту має певні смислові частини, які умовно можна поділити на зав'язку (початок подій), кульмінацію (основну частину) й розв'язку (завершення подіi).

У тексті-описі відображаються характеристики певного предмета, явища, людини, тощо. Головною метою такого типу тексту є створення в уяві читача образа про об’ект, що описуеться, таким чином, аби він відповідав творчому задуму автора. На відміну від тексту-розповіді, текст-опис може не мати чіткої структури. Головним інструментом у даному випадку є майстерність автора у володінні словом і вміння художньо висловити побачене, почуте, або відчуте. Проте, як зазначає Олена Лобчук [1], деякі логічні частини також можуть бути, зокрема: частина з загальним описом, частина 3 деталізацією ознак предмета, що підтверджують загальну характеристику, підсумкова частина.

Текст-міркування - це текст, у якому за допомогою логічної побудови відбувається розкриття сутності теми. Такий текст має бути структурованим, з певною ідеею, яка закладається на початку, з частиною, яка містить обговорення ідеї, або іiї доведення, якщо це можливо, і обов'язково з заключною частиною. Такий тип тексту характерний для наукових публікацій, ділової переписки й інших сфер діяльності. 
На цьому етапі роботи 3 метою формування в учнів початкової школи вміння розрізняти типи текстів рекомендуємо вчителеві застосовувати такі види роботи: аналіз допоміжних матеріалів для написання текстів; аналіз усього тексту, його смислових частин, окремих фррагментів; аналіз власного тексту. Надзвичайно важливо, щоб учні на всіх етапах вивчення української мови навчалися будувати різні типи текстів, удосконалювали власні мовленневі вміння висловлювати власні думки, уміли знаходити помилки і виправляти їх під час редагування текстів.

Деталізуемо систему організаційно-методичної роботи, яка може бути застосована вчителем початкової школи на уроках вивчення теми «Типи текстів» (розповідь, опис, міркування, есе). Підкреслимо, що серед головних завдань запропонованої системи є не лише робота 3 ознайомлення учнів із різними типами текстів, а й робота 3 опанування ними вміннями й навичками створювати тексти різних типів. Таким чином, запропонована система роботи може бути використана в освітньому процесі на уроках української мови в початковій школі з метою формування текстотворчих умінь молодших школярів.

Організаційно-методична система роботи передбачає три етапи. На першолу етапі вчитель пояснюе дітям основний навчальний матеріал щодо розрізнення типів тексту і на конкретних прикладах розкриває сутність кожного 3 типів тексту. Даний етап вимагає від учителя початкової школи грунтовної підготовки до уроку і майстерного пояснення навчального матеріалу. Педагог має здійснити ретельний відбір методичних матеріалів із урахуванням індивідуальних особливостей кожного учня.

Важливо зазначити, що добір матеріалу має передбачати не лише використання конкретних прикладів текстів, а також містити ілюстрації рисунки, аудіо та відео записи тематичної спрямованості. Це дасть змогу вчителеві побудувати роботу на уроці української мови в невимушеній ігровій атмосорері, що забезпечить максимально ефрективне сприйняття інфрормації. Наприкінці уроку вчитель має підбити підсумок і шляхом опитування учнів зрозуміти для себе рівень засвоєння навчального матеріалу та проблеми, які виникли у дітей в розумінні теми уроку.

Ha друголу еmani має відбуватися практичне засвоєння учнями матеріалу теми та набуття навичок, що пов'язані з умінням розпізнавати типи текстів. 3 цією метою учням пропонується виконати вправи і завдання, спрямовані на роботу з текстами різних типів. Підготовка вправ може здійснюватися вчителем із використанням матеріалів, які наявні в лінгводидактичній літературі, а також можуть бути розроблені педагогом власноруч. Очікуеться, що вправи, розроблені вчителем особисто, будуть більш ефективними і сприятимуть засвоєнню матеріалу, оскільки під час їх укладання вчитель може враховувати результати опитування учнів за результатами першого етапу.

У сучасних умовах учитель, укладаючи комплекс вправ, має враховувати наявні у школі і в дітей можливості застосування інформаційних та телекомунікаційних технологій. Зокрема, педагог може створювати вправи на різних платорормах із використанням програмного забезпечення, що знаходиться у вільному доступі, наприклад, популярні сервіси Google.

Ha mретьолу еmani учні навчаються створювати різні типи текстів. Беручи до уваги ті знання і вміння, якими молодші школярі оволоділи під час вивчення типології текстів, учні потенщійно можуть самостійно складати тексти різних типів. Робота учнів на даному етапі $є$ значною мірою творчою і вимагае застосування різних мовленневих умінь і глибинних навичок, здобутих протягом усього періоду навчання української мови. Тому не слід очікувати, що всі учні в однаковій мірі добре зможуть складати тексти різних типів.

У зв'язку з цим головним завданням учителя на цьому етапі $є$ проведення ретельної роботи 3 добору і створення комплексу вправ та завдань для учнів, які враховують індивідуальні особливості кожної дитини. Головним принципом у такій роботі є не складність і витонченість побудови вправ, а саме доступність у розумінні для кожного конкретного учня. За результатами даного етапу кожен учень на своєму рівні має оволодіти новою для себе компетенцією - умінням створювати тексти різних типів. При џьому має бути забезпечений той рівень знань, текстотворчих умінь і компетенцій, аби надалі кожен учень уже міг самостійно їх розвивати й удосконалювати.

3 боку організаційно-методичної реалізації запропонованої системи роботи, головним завданням якої $є$ формування в учнів молодшого шкільного віку вміння будувати різні типи текстів, ключову роль відіграють вправи і завдання, які вчитель використовуе під час уроку. Добір вправ є одним із найважливіших елементів підготовки до уроку і вимагає досвіду й певної педагогічної інтуїції вчителя початкової школи. Слід зазначити, що педагог може також розробляти зміст вправ власноруч, що значно покращить рівень сприйняття навчального матеріалу і його засвоення.

Детально розглянемо типи вправ, які доцільно застосовувати на уроках української мови 3 метою формування таких текстотворчих умінь учнів початкової школи.

Перший mun вправ пов'язаний із читанням невеликих за обсягом фрагментів текстів і характеристикою цього тексту. При цьому важливо не обмежуватися короткою відповіддю на запитання, який це тип тексту. Потрібно, щоб учні давали розгорнуту відповідь, у якій зазначали б смислові частини тексту, характеризували кожний його фрагмент і формулювали основну ідею тексту. У вправах цього типу можуть використовуватися як письмові тексти, так і аудіо- та відеозаписи різних фррагментів тексту. Застосування відеозаписів сприятиме формуванню в учнів певних асоціацій між текстами різного типу й їхніми зображеннями, що, як правило, покращуе сприйняття навчального матеріалу. Проте, важливо зазначити, що використання відео- та аудіо-матеріалів під час пояснення нового матеріалу має бути допоміжним інструментом і ніякою мірою не має повністю замінювати письмовий текст.

Другий mun вправ - тестові завдання 3 варіантами відповіді. Виконання вправ такого типу має займати в учнів небагато часу i має бути спрямоване на те, щоб кожний учень міг закріпи- 
ти почуту на уроці інформацію про типи текстів, а вчитель мав змогу оцінити рівень сприйняття навчального матеріалу про типологію текстів.

Важливо, що організаційно-методична реалізація даного типу вправ можлива із залученням сучасних інформаційних і телекомунікаційних технологій i може здійснюватися дистанційно. Зокрема, створення тестів можливе за допомогою опитувальників, закладених у сервіси Google, які є у вільному доступі. Таким чином, учні, прослухавши навчальний матеріал про типи текстів (перший етап запропонованої системи організаційно-методичної реалізації), можуть відповісти на запитання тестів у будь-який зручний для них час і у будь-якому зручному місці, що, з одного боку, буде економити час уроку, a, з іншого боку, полегшить учителеві процес перевірки тестових завдань, який може здійснюватися в автоматичному режимі: учитель одержуе одразу підсумкові результати, що генеруються програмою.

Tретіŭ mun вправ - творчі вправи, пов'язані з завданнями написати текст певного типу (розповідь, опис, міркування, есе). Під час застосування такого типу вправ учитель має бути готовий до того, що в класі завжди будуть учні, для яких написання різних типів текстів не викликатиме значних труднощів, але також будуть і такі діти, для яких такі завдання будуть занадто складними. Це є природнім, оскільки процес формування текстотворчих умінь у молодших школярів відбувається неоднаково і вимагає певного часу. У цьому випадку учням можна запропонувати спочатку написати план тексту і попросити їх розповісти текст за складеним планом. Як наступний крок, школярам можна запропонувати створити текст за поданим планом відповідно до своєї розповіді.

Важливим елементом такої роботи є обговорення й аналіз виконаних учнями завдань, написаних школярами текстів. На нашу думку, така колективна робота забезпечить розуміння навчального матеріалу тими учнями, які підготували власний текст і разом з усіма його аналізують, а також тими учнями, які беруть участь в обговоренні тексту, що написаний іншими.

Зазначимо, що в даному випадку така робота вчителя вимагає особливих зусиль як на стадії підготовки навчальних матеріалів для уроку, так і на самому уроці. Адже матеріал має бути поданий цікаво і доступно для учнів початкової школи. На уроці української мови вчитель має майстерно пояснювати тему уроку і забезпечувати сконцентрованість уваги учнів протягом необхідного періоду часу. Для цього рекомендуємо педагогові поєднувати ті фрагменти уроку, які вимагають зосередженої індивідуальної роботи учня, з тими фрагментами, коли учень може працювати в ігровій формі колективно.

Висновки і пропозиції. Робота над різними типами текстів має важливе значення для розвитку мовленневих умінь і навичок учнів початкової школи. У сучасній початковій школі цей напрям роботи недостатньо розроблений і потребуе особливої уваги. На нашу думку, учителі мають формувати в молодших школярів текстотворчі вміння на кожному уроці української мови.

Достатній рівень сорормованості вміння будувати різні типи текстів свідчить про належний рівень мовленнєвого розвитку, якого має досягти в навчанні української мови кожен учень. Робота над текстами різних типів, яка передбачає навчання створювати власні висловлювання, визначення основних характеристик текстів, уміння аналізувати ї структурні частини й усвідомлювати головну думку, що висловлюеться в тексті, розвиває в учнів уміння застосовувати загально фрілософрські методи аналізу та синтезу й критично мислити. Така робота сприяе розвитку культури мовлення учнів, підвищує загальний інтелектуальний рівень молодших школярів, посилює вже існуючі вміння і навички й відкриває можливості для оволодіння новими.

Проблема формування в учнів початкової школи вміння будувати різні типи текстів вимагає особливої уваги й подальших досліджень. Зокрема, варто зазначити питання, що потребують подальшого висвітлення:

- пошук нових доцільних методів і прийомів роботи, які активізують процес формування текстотворчих умінь;

- розроблення системи вправ і завдань, яка спрямована на формування в учнів початкової школи вміння будувати різні типи текстів;

- застосування сучасних інформаційних технологій на уроках формування текстотворчих умінь і навичок учнів.

\section{Список літератури:}

1. Богданець-Білоскаленко Н.І. Текст як інструмент формування ключових компетентностей учнів початкових класів на уроках української мови в школах із мовою навчання національних меншин. Українська мова у cвimi : збірник матеріалів 6 міжнар. наук.-практ. конф. ТзОВ «Галицька видавнича спілка». Львів, 2020. C. $22-24$.

2. Божко О.П. Формування текстотворчих умінь учнів основної школи в процесі вивчення синтаксису складного речення : дис. канд. пед. наук : 13.00.02. Херсонський держ. ун-т. Херсон, 2017. 283 с.

3. Дорошенко C.I. Розвиток мовлення молодших школярів. Київ : Освіта, 2017. 124 с.

4. Дубовик С.Г., Повдешна О.О. Формування в молодших школярів умінь редагувати тексти. Молодий вчений. 2020. № 3(79). С. 105-109.

5. Кохно Т.Н. Формування мовленневої компетентності в учнів 3-4 класів на уроках розвитку мовлення у 33 СО 3 навчанням мовами національних меншин. Українська мова і література в школі. 2019. № 5(146). С. 61-64.

6. Лобчук О.Г. Ознайомлення молодших школярів з типами текстів. Сучасна школа України. 2012. № 4. С. 48-51.

7. Луцан Н. Лінгводидактичні засади розвитку вмінь будувати висловлювання у молодшому шкільному віці. Науковий Вісник МНУ ілені В.О. Сухоллинського. Педагогічні науки. 2017. № 4(59). С. 300-304.

8. Пономарьова К.І. Реалізація змістових ліній початкового курсу мовно-літературної освіти в 2-му класі // Учитель початкової школи. 2019. № 3(70). С. 6-11.

9. Пономарьова К.І. Формування комунікативної компетентності молодших школярів у процесі навчання української мови : посібник. КОНВІ ПРІНТ. Київ, 2020. 88 с. 


\section{References:}

1. Bogdanets-Biloskalenko N.I. (2020) Tekst yak instrument formuvannya klyuchovykh kompetentnostey uchniv pochatkovykh klasiv na urokakh ukrayins'koyi movy v shkolakh iz movoyu navchannya natsional'nykh menshyn [Text as a tool for forming key competencies of primary school students in Ukrainian language lessons in schools with the language of instruction of national minorities]. Proceedings of the 6 International Scientific and Practical Conference Ukrainian language in the world. Lviv: TzOV Halyts'ka Vydavnycha Spilka, pp. 22-24.

2. Bozhko O.P. (2017) Formuvannya tekstotvorchykh umin' uchniv osnovnoyi shkoly v protsesi vyvchennya syntaksysu skladnoho rechennya [Formation of text-making skills of primary school students in the process of studying the syntax of a complex sentence] (PhD Thesis), Kherson: Kherson State University.

3. Doroshenko S.I. (2017) Rozvytok movlennya molodshykh shkolyariv [Speech development of junior schoolchildren]. Kyiv: Osvita. (in Ukrainian)

4. Dubovyk S., Povshedna O. (2020) Formuvannya v molodshykh shkolyariv umin' redahuvaty teksty [Formation in young pupils of text editing skills]. Young Scientist, no. 3(79), pp. 105-109.

5. Kokhno T.N. (2019) Formuvannya movlennyevoyi kompetentnosti v uchniv 3-4 klasiv na urokakh rozvytku movlennya u ZZSO z navchannyam movamy natsional'nykh menshyn [Formation of speech competence in students of 3-4 grades in lessons of speech development in ZZSO with teaching in languages of national minorities]. Ukrainian Language and Literature at School, no. 5(146), pp. 61-64.

6. Lobchuk O.H. (2012) Oznayomlennya molodshykh shkolyariv z typamy tekstiv [Acquaintance of junior schoolchildren with types of texts]. Modern School of Ukraine, no. 4, pp. 48-51.

7. Lutsan N. (2017) Linhvodydaktychni zasady rozvytku vmin buduvaty vyslovlyuvannya u molodshomu shkilnomu vitsi [Linguodidactic principles of development of skills to build expressions in primary school age]. Scientific Bulletin of VO Sukhomlinsky MNU. Pedagogical Sciences, no. 4(59), pp. 300-304

8. Ponomareva K.I. (2019) Realizatsiya zmistovykh liniy pochatkovoho kursu movno-literaturnoyi osvity v 2 -mu klasi [Implementation of the content lines of the initial course of language and literature education in the 2nd form]. Primary School Teacher, no. 3(70), pp. 6-11.

9. Ponomareva K.I. (2020) Formuvannya komunikatyvnoyi kompetentnosti molodshykh shkolyariv u protsesi navchannya ukrayins'koyi movy: posibnyk [Formation of communicative competence of junior schoolchildren in the process of learning the Ukrainian language: methodical manual]. Kyiv: CONVI PRINT. (in Ukrainian) 